\title{
KEDUDUKAN DAN AKIBAT HUKUM PENERAPAN PERMA NO.2 TAHUN 2012
}

\section{Fadliansyah}

Fakultas Hukum Universitas Borneo Tarakan

Fadliansyah_sh@yahoo.com

\begin{abstract}
Abstrac
This research was made to know the position of PERMA NO.2 IN 2012 in the hierarchy of legislation and to know the PERMA's binding and enforceability. In this research using normative law research method with law approach, conceptual, and case approach. From this study found that the position of PERMA NO.2 IN 2012 in the hierarchy of legislation - legislation is under the law and the effect of the implementation of PERMA is null and void.
\end{abstract}

Keywords: position, PERMA NO.2 IN 2012, Due to the law

\begin{abstract}
Abstrak
Penelitian ini dibuat untuk mengetahui kedudukan PERMA NO.2 TAHUN 2012 dalam hierarki peraturan perundang - undangan dan untuk mengetahui kekuatan mengikat dan keberlakuan PERMA tersebut. Dalam penelitian ini menggunakan metode penelitian hukum normative dengan pendekatan undang - undang, konseptual, serta pendekatan kasus. Dari penelitian ini ditemukan bahwa kedudukan PERMA NO.2 TAHUN 2012 dalam hierarki perundang undangan adalah dibawah undang - undang dan akibat dari diterapkannya PERMA tersebut adalah batal demi hukum.
\end{abstract}

Kata kunci : kedudukan, PERMA NO.2 TAHUN 2012, Akibat hukum

\section{PENDAHULUAN}

KUHP merupakan induk peraturan positif mengenai tindak pidana yang berlaku untuk pulau jawa dan madura sejak dibentuknya Undang - undang Nomor 1 Tahun 1946 Tentang Peraturan Hukum Pidana ( Lembaran Negara Republik Indonesia Tahun 1946 Nomor, selanjutnya disingkat menjadi UU No.1/1946 ) Dan berlaku secara nasional sejak dibentuknya Undang - undang Nomor 73 Tahun 1958 Tentang Menyatakan Berlakunya Undang - Undang 
Nomor 1 Tahun 1946 Republik Indonesia Tentang Peraturan Hukum Pidana Untuk Seluruh Wilayah Republik Indonesia Dan Mengubah Kitab Undang Undang Hukum Pidana ( Lembaran Negara Republik Indonesia Tahun 1958 Nomor, selanjutnya disingkat menjadi UU No.73/1958 ). Selanjutnya pada tanggal 14 April 1960 diadakan penyesuaian berkaitan dengan harga barang yang tercantum dalam pasal 364, 373,379,384, dan 407 ayat (1) KUHP dengan dibentuknya Peraturan Pemerintah Pengganti Undang - Undang Republik Indonesia Nomor 16 Tahun 1960 Tentang Beberapa Perubahan Dalam Kitab Undang - Undang Hukum Pidana Republik Indonesia ( Lembaran Negara Republik Indonesia Tahun 1960 Nomor 50, Tambahan Lembaran Negara Republik Indonesia Nomor 1976, selanjutnya disingkat menjadi PERPU NO.16/1960 ). Inti dari PERPU tersebut adalah mengadakan penyesuaian harga barang yang tercantum dalam pasal 364,373,379,384, dan 407 ayat (1) KUHP, dari dua puluh lima Rupiah menjadi dua ratus lima puluh Rupiah.

Penyesuaian nilai pada harga barang dalam KUHP saat itu dianggap sebagai suatu keadaan yang memaksa sehingga perlu dibentuk PERPU NO.16/1960 yang kemudian disahkan menjadi undang - undang melalui Undang - Undang Nomor 1 Tahun 1961 Tentang Pengesahan Semua Undang Undang Darurat dan Peraturan Pemerintah Pengganti Undang - Undang Menjadi Undang - Undang ( lembaran Negara Republik Indonesia Tahun 1961 Nomor, selanjutnya disingkat menjadi UU No.1/1961 ) karena nilai harga barang pada pasal - pasal tersebut sudah tidak sesuai dengan keadaan pada saat itu.

Sejak tahun 1960 hingga akhir tahun 2011 pemerintah belum mengadakan penyesuaian mengenai nilai harga barang dalam KUHP, khususnya pasal - pasal yang berkaitan dengan tindak pidana ringan dalam hal kejahatan terhadap harta benda milik orang lain, sehingga mengakibatkan ketentuan pasal 364,373,379,384, 407, dan 482 KUHP sulit untuk diterapkan, mengingat hampir tidak pernah terjadi tindak pidana seperti pencurian, penggelapan, penipuan, 
perbuatan curang, pengrusakan, atau penadahan, pendek kata kejahatan terhadap harta benda yang harga barangnya Rp.250,- ( dua ratus lima puluh rupiah ) atau bawah Rp.250,- ( dua ratus lima luluh rupiah ).

Akibat dari belum diadakannya penyesuaian terhadap harga barang yang tercantum dalam KUHP sejak tahun 1960, maka beberapa ketentuan yang berkaitan dengan tindak pidana yang tergolong kejahatan ringan terhadap harta benda tidak dapat diterapkan, misalkan perkara nenek inisial $\mathrm{M}$ yang didakwa melakukan pencurian tiga buah kakao pada suatu hari di bulan Agustus tahun 2009 di desa Darmakradenan Kecamatan Ajibarang, Banyumas jawa tengah yang harganya \pm Rp 30.000,- (lebih kurang tiga puluh ribu rupiah ) (Putusan Nomor : 247/Pid.B/2009/PN.PWT), atau perkara seorang pelajar SMK inisial AAl, yang didakwa melakukan pencurian sepasang sandal merek Ando berwarna putih di kelurahan Birobuli kecamatan Palu Selatan Kota Palu pada bulan November tahun 2010 yang harganya \pm Rp. 35.000,- ( tiga puluh lima ribu rupiah ) ( putusan nomor 31/Pid.Anak/2011/PN.PL selanjutnya dikuatkan dengan putusan pengadilan tinggi nomor 04/Pid.sus/2012/PT.PALU ). Menurut Ahmad Bahiej49, keberlakuan hukum pidana di Indonesia sebenarnya sangat erat kaitannya dengan rasa keadilan masyarakat. Persoalan kesesuaian antara hukum pidana dengan masyarakat dimana hukum pidana tersebut diberlakukan menjadi salah satu prasyarat baik atau tidaknya hukum pidana. Artinya, hukum pidana dianggap baik jika memenuhi dan berkesuaian dengan nilai - nilai yang dimiliki masyarakat. Sebaliknya hukum pidana dianggap buruk jika telah usang dan tidak sesuai dengan nilai - nilai dalam masyarakat.

Selain untuk mengikuti nilai- nilai keadilan yang hidup dalam masyarakat, pembedaan tindak pidana ringan dengan tindak pidana biasa dan tindak pidana berat adalah agar proses pemeriksaan perkara pidana tersebut dilaksanakan secara proporsional sesuai dengan kualitas tindak pidananya. Berdasarkan

\footnotetext{
${ }^{49}$ Ahmad Bahiej, Sejarah dan Problematika Hukum Pidana Materiel di Indonesia, Sosio Religia,Vol.4 No.4 Agustus 2005, h.2
} 
ketentuan pasal 205 Undang - undang Nomor 8 Tahun 1981 Tentang Hukum Acara Pidana ( Lembaran Negara Republik Indonesia Tahun 1981 Nomor 76, Tambahan Lembaran Negara Nomor 3209, selanjutnya disingkat menjadi KUHAP ) berbunyi " yang diperiksa menurut acara pemeriksaan tindak pidana ringan ialah perkara yang diancam dengan pidana penjara atau kurungan paling lama tiga bulan dan atau denda sebanyak - banyaknya tujuh ribu lima ratus rupiah dan penghinaan ringan kecuali yang ditentukan dalam paragraph 2 bagian ini ". bahwa berdasarkan ketentuan pasal tersebut maka tindak pidana ringan diperiksa dengan acara pemeriksaan cepat. Dalam acara pemeriksaan cepat Pengadilan mengadili dengan hakim tunggal pada tingkat pertama dan terakhir, kecuali dalam hal putusan hakim menjatuhkan putusan pidana yang bersifat perampasan bagi kemerdekaan terdakwa, maka terdakwa dapat mengajukan banding. Penuntutan dalam acara pemeriksaan cepat dilakukan oleh penyidik atas kuasa penuntut umum. Selain itu terhadap tersangka atau terdakwa pelaku tindak pidana ringan tidak dilakukan penahanan karena ancaman pidana penjaranya dibawah lima tahun yakni paling lama tiga bulan.

Berkaitan dengan masalah tersebut diatas, maka Mahkamah Agung membentuk Peraturan Mahkamah Agung Republik Indonesia Nomor 2 Tahun 2012 tentang Penyesuaian Batasan Tindak Pidana Ringan dan Jumlah Denda Dalam KUHP ( selanjutnya disingkat menjadi PERMA No.2 Tahun 2012) . Isi dari peraturan ini adalah mengadakan penyesuaian nilai rupiah dan jumlah denda yang ada dalam pasal 364,373,379,384,407 dan pasal 482 KUHP dari harga barang Rp.250,- ( dua ratus lima puluh rupiah ) menjadi Rp.2.500.000,- ( dua juta lima ratus ribu rupiah ) dan mengenai hukuman denda dilipatgandakan 1000 ( seribu ) kali, mengingat belum pernah diadakannya penyesuaian berkaitan dengan dua hal tersebut sejak tahun 1960. Bahwa yang menjadi dasar penyesuaian tersebut adalah perbandingan harga emas sejak tahun 1960 sampai dengan tahun 2012. 


\section{Rumusan Masalah}

Berdasarkan uraian latar belakang masalah diatas, maka yang menjadi rumusan masalah adalah :

“ KEDUDUKAN DAN AKIBAT HUKUM PENERAPAN PERMA NO.2 TAHUN 2012 “

\section{Metode penelitian.}

\section{Tipe penelitian.}

Menurut tipe penelitian dalam tesis ini adalah normatif. Pendekatan pendekatan yang digunakan di dalam penelitian hukum adalah pendekatan undang - undang (statute approach), pendekatan ----- kasus (case approach), pendekatan historis ( historical approach), pendekatan komparatif ( comparative approach ) dan pendekatan konseptual ( conceptual approach). ${ }^{50}$

\section{PEMBAHASAN}

Undang - undang merupakan sumber hukum yang penting dan utama. Akan tetapi perlu diingat bahwa undang - undang dan hukum tidaklah identik. Sumber hukum pidana di Indonesia adalah sebagai berikut :

1) KUHP ( sejak di bentuknya Undang - undang Nomor 1 Tahun 1946 Tentang Peraturan Hukum Pidana, PHP (peraturan hukum pidana) berlaku untuk pulau jawa dan madura Dan berlaku secara nasional sejak dibentuknya Undang - undang Nomor 73 Tahun 1958 Tentang Menyatakan Berlakunya Undang - Undang Nomor 1 Tahun 1946 Republik Indonesia Tentang Peraturan Hukum Pidana Untuk Seluruh Wilayah Republik Indonesia Dan Mengubah Kitab Undang - Undang Hukum Pidana ( KUHP) (Lembaran Negara Republik Indonesia Tahun 1958 Nomor 127, Tambahan Lembaran Negara Tahun 1958 Nomor 1660 );

2) Dan semua undang - undang di luar KUHP yang mengatur ketentuan pidana. Pada sisi lain diterapkannya ketentuan pasal - pasal dalam KUHP yang mengatur tentang tindak pidana ringan dirasakan sudah tidak sesuai dengan situasi dan kondisi sosial masyarakat pada saat ini , sehingga penerapan pasal pasal dalam KUHP yang mengatur tentang tindak pidana ringan jauh dari rasa

\footnotetext{
50 ibid.h.133
} 
keadilan atau bertentangan dengan rasa keadilan yang hidup dalam masyarakat. Untuk mengetahui alasan diterapkannya PERMA No.2 Tahun 2012 , maka perlu ditelaah rasio decidendi suatu putusan tersebut, khususnya putusan yang berdasarkan PERMA No.2 Tahun 2012 . dalam hal ini putusan yang didasarkan atas eksepsi, adapun putusan yang dijadikan bahan analisis yaitu Putusan Nomor : 553/Pid.B/2012/PN.Stb dan Putusan Sela Nomor : 327/Pid.B/2012/PN.SKG.

1) Putusan Nomor : 553/Pid.B/2012/PN.Stb

Menimbang bahwa pasal 8 ayat 1 Undang-Undang Nomor 12 tahun 2011, tentang " Pembentukan Peraturan Perundang-Undangan" menyebutkan bahwa "Jenis peraturan PerUndang-Undangan selain dimaksud dalam pasal 7 ayat 1 mencakup juga peraturan yang ditetapkan oleh :MPR, DPR, MAHKAMAH AGUNG, MAHKAMAH KONSTITUSI, BPK, KY, BI, MENDTERI, $B A D A N, \ldots .$. , maka bersandar pada bunyi pasal 8 ayat 1 tersebut, Majelis menilai tentunya Perma dan Sema adalah juga merupakan bahagian dari peraturan yang ditetapkan MAHKAMAH AGUNG

Menimbang bahwa selanjutnya pasal 8 ayat 2 Undang-Undang Nomor 12 tahun 2011 meletakkan syarat " bahwa peraturan-perundang-undangan sebagaimana dimaksud pada ayat (1) diakui keberadaannya dan mempunyai kekuatan hukum mengikat sepanjang diperintahkan oleh Peraturan Perundang-Undangan yang lebih tinggi atau dibentuk berdasarkan kewenangan “

Menimbang bahwa hal tersebut sejalan dengan pasal 79 Undang-Undang Nomor 14 tahun 1985 sebagaimana telah diubah dengan Undang-Undang nomor 5 tahun 2004 dan juga telah diubah dengan Undang-Undang nomor 3 tahun 2009 yang menyebutkan bahwa "Mahkamah Agung dapat mengatur lebih lanjut hal-hal yang diperlukan bagi kelancaran penyelenggaraan Peradilan apabila terdapat hal-hal yang belum cukup diatur dalam Undang-Undang ini “

Menimbang bahwa apabila kemudian diperhatikan semangat/roh dari PERMA nomor 02 tahun 2012 tersebut yang terkandung dalam Penjelasan PERMA tersebut, maka dapat diketahui latar belakang kebutuhan hukum Nasional yang kemudian diketahui sebagai hal yang menyemangati lahirnya PERMA tersebut, dimana disebutkan banyaknya perkara pencurian selain telah membebani Pengadilan dari segi anggaran 
juga banyaknya perkara pencurian dengan nilai barang yang rendah yang kini diadili di Pengadilan cukup mendapatkan sorotan masyarakat, karena masyarakat menilai sangatlah tidak adil jika perkara-perkara demikian diancam dengan hukuman 5 (lima) tahun sebagaimana diatur dalam pasal $362 \mathrm{KUHP}$, oleh karena tidak sebanding dengan nilai barang yang dicuri, oleh karena batasan pencurian ringan yang diatur dalam pasal 364 KUHP saat ini adalah barang atau uang yang nilainya di bawah Rp.250.-(dua ratus lima puluh rupiah) dirasakan sudah tidak sesuai lagi saat ini dikarenakan sudah hampir tidak ada barang yang nilainya di bawah Rp.250,- tersebut, dan mengingat sepertinya hal tersebut saat ini belum menjadi prioritas perhatian Pemerintah dan DPR, selain itu proses perubahan KUHP oleh Pemerintah dan DPR akan memakan waktu yang cukup lama, sehingga Mahkamah Agung memandang perlu menerbitkan Peraturan Mahkamah Agung untuk menyesuaikan nilai uang yang menjadi batasan suatu tindak pidana ringan.

Menimbang bahwa berangkat dari pemahaman kedua pasal dari kedua Undang- Undang di atas yaitu Undang-Undang nomor 12 tahun 2011 dan Undang-Undang nomor 14 tahun 1985 dan perubahannya, serta jiwa/roh yang menyemangati PERMA tersebut, maka jelas dapat diketahui bahwa Peraturan Mahkamah Agung (Perma) juga merupakan bagian dari Perundang-Undangan sebagaimana dimaksud dalam UndangUndang nomor 12 tahun 2011, oleh karenanya juga berlaku mengikat terhadap semua lembaga penegak hukum lainnya secara Nasional selama tidak dibatalkan dengan uji materi ke Mahkamah Agung (vide pasal 9 ayat 2 Undang-Undang Nomor 12 tahun 2011), maka tetap berlaku sepanjang masa.

Menimbang bahwa setelah Majelis meyakini bahwa PERMA nomor 02 tahun 2012 adalah sebagai peraturan yang mempunyai daya mengikat dari pasal perpasal, terlebih bagi Majelis sendiri, oleh karenanya segala ketentuan yang tertera dalam PERMA tersebut harus juga diyakini sebagai bahagian dari Hukum Acara Pidana disamping yang diatur dalam KUHAP yang berlaku di Indonesia.

Majelis berpendapat Eksepsi dari Penasehat Hukum Terdakwa tersebut cukup berdasar hukum apabila kita memperhatikan pasal 2 dari PERMA nomor 02 tahun 2012 tersebut di atas, mengingat apabila dilihat dari Surat Dakwaan Penuntut Umum sendiri yang menyebutkan bahwa kerugian yang diderita korban akibat dari tindak pidana pencurian tersebut adalah sebesar Rp.200.000 (dua ratus ribu rupiah), oleh karenanya sudah seharusnya Penuntut Umum dalam hal ini tadinya mengembalikan berkas perkara aquo ke Penyidik, supaya Penyidik melimpahkan perkara aquo ke Pengadilan dengan menggunakan 
Pemeriksaan Acara Cepat sebagaimana diamanatkan dalam PERMA nomor 02 tahun 2012 tersebut dan tidak dengan menggunakan Acara Pemeriksaan Biasa sebagaimana yang telah diperiksa dalam Persidangan ini.

Menimbang bahwa dengan demikian, maka cukup beralasan dan berdasarkan hukum juga Majelis dalam perkara ini menerima Eksepsi dari Penasehat Hukum Terdakwa dengan menyatakan bahwa Proses Penuntutan Penuntut Umum tidak dapat diterima dan mengembalikan berkas perkara Nomor 553/Pid.B/2012/PN.Stb kepada Penuntut Umum, serta memerintahkan Penuntut Umum untuk mengembalikan berkas perkara aquo kepada Penyidik dan melimpahkannya kembali dengan Acara Pemeriksaan Cepat.

Berdasarkan beberapa bertimbangan tersebut diatas, dapat diketahui bahwa yang menjadi dasar dari digunakannya PERMA No.2 tahun 2012 adalah semangat atau roh dari pembentukan PERMA No.2 Tahun 2012 yang ingin menegakkan keadilan secara proporsional, khususnya terhadap perkara tindak pidana ringan dan dasar yang kedua adalah majelis hakim berpendapat bahwa PERMA No.2 Tahun 2012 sebagai salah satu bentuk peraturan perundang undangan yang ada dalam sistem hukum di Indonesia, berlaku dan memiliki kekuatan mengikat selama tidak dibatalkan melalui uji materil ke Mahkamah Agung.

2) Putusan Sela : 327/Pid.B/2012/PN.SKG

Menimbang, bahwa selanjutnya akan dipertimbangkan apakah sehubungan dengan diterbitkannya PERMA No. 02 Tahun 2012 Tentang Penyesuaian Batasan Tindak Pidana Ringan dan Jumlah Denda Dalam KUHP (ditetapkan pada tanggal 27 Februari 2012) tersebut Majelis Hakim Pengadilan Negeri Sengkang berwenang memeriksa dan mengadili perkara ini, majelis berpendapat sebagai berikut:

Menimbang, setelah majelis memperhatikan dan meneliti berkas perkara tersebut dimana kerugian yang dicantumkan dalam surat dakwaan adalah Rp. 1.000.000,(satu juta rupiah), hal tersebut bersesuaian dengan keterangan saksi korban bernama Cebbang Bin Sapareng dalam BAP Penyidik bahwa dirinya menderita kerugian materi sekitar Rp. 2.500.000,- dan juga merasa harga dirinya di injak-injak serta dalam halaman lainnya menerangkan pula bahwa : khusus untuk kerusakan pagar kayu Jawa sekitar 20 batang sepanjang 18 meter sekitar Rp.1.000.000,- serta kerugian lain yaitu harga dirinya dinjak-injak. Dengan demikian dapat 
disimpulkan bahwa kerugian yang kemungkinan diderita oleh korban tersebut tidak lebih dari Rp. 2.500.000,-;

Menimbang, bahwa berdasarkan hal tersebut jika dikaitkan dengan PERMA No. 02 Tahun 2012 Tentang Penyesuaian Batasan Tindak Pidana Ringan dan Jumlah Denda Dalam KUHP sebagaimana pasal 2 Ayat (2) maka diperiksa dengan Acara Pemeriksaan Cepat yang diatur dalam pasal 205 - 210 KUHAP;

Menimbang, bahwa terhadap tanggapan Penuntut Umum atas Eksepsi Penasehat Hukum Terdakwa yang pada pokoknya bahwa PERMA No. 02 Tahun 2012 Tentang Penyesuaian Batasan Tindak Pidana Ringan dan Jumlah Denda Dalam KUHP tersebut baru bisa dilaksanakan apabila Pengadilan Negeri telah mensosialisaikannya Kepada kejaksaan Negeri, Majelis berpendapat sebagai berikut:

Menimbang, bahwa dengan memperhatikan Nota Kesepakatan Bersama : Ketua Mahkamah Agung Republik Indonesia; Menteri Hukum Dan Hak Asasi Manusia Republik Indonesia; Jaksa Agung Republik Indonesia; Kepala Kepolisian Negara Republik Indonesia tentang Pelaksanaan Penerapan Penyesuaian Batasan Tindak Pidana Ringan dan Jumlah Denda, Acara Pemeriksaan Cepat, Serta Penerapan Keadilan Restoratif : Nomor 131/KMA/SKB/ X/2012; Nomor M. HH - 07.HM.03.02 Tahun 2012; Nomor KEP - 06 / E / EJP / 10 / 2012; Nomor B / 39 /X/2012 pada hari Rabu tanggal 17 Oktober 2012 maka sosialisasi antar lembagalembaga tinggi yang berkepentingan tersebut telah dilaksanakan namun masih terkendala dengan adanya sosialisasi pada tingkat bawah (Pengadilan Negeri, Kejaksaan Negeri, Polres serta Lembaga Pemasyarakatan / Rutan);

Menimbang, bahwa berdasarkan hal tersebut di atas dan untuk mewujudkan Peradilan yang cepat, sederhana dan biaya ringan dengan mempertimbangkan Rasa keadilan dalam masyarakat maka perkara tersebut sepatutnya diajukan dalam persidangan dengan Acara Pemeriksaan Cepat, dengan demikian Majelis hakim Pengadilan Negeri Sengkang yang memeriksa dan mengadili perkara ini, harus menyatakan dakwaan Penuntut Umum Tidak dapat diterima;

Dari uraian beberapa pertimbangan diatas dapat diketahui bahwa yang menjadi dasar majelis hakim menerapkan PERMA No.2 tahun 2012 adalah Nota Kepakatan Bersama. 
Untuk menelaah kedua putusan tersebut diatas maka, diperlukan pembahasan mengenai kedudukan PERMA No.2 Tahun 2012 dalam hierarki perundang - undangan, selanjutnya mengenai kekuatan berlaku dan kekuatan mengikat dari PERMA No.2 Tahun 2012, diteruskan pembahasan mengenai alasan hakim menerapkan PERMA No.2 Tahun 2012, diakhiri dengan pembahasan

1. Kedudukan PERMA No.2 Tahun 2012 dalam hierarki peraturan perundang - undangan Indonesia.

Menurut Zevenbergen yang dikutip oleh Satjipto Rahardjo, Norma hukum memeuat suatu penilaian mengenai perbuatan tertentu. Hal itu paling jelas tampak dalam bentuk suruhan dan larangan. Oleh karena itu untuk memastikan, apakah di situ kita menjumpai suatu norma hukum atau tidak, keduanya bisa dipakai sebagai ukuran. Dengan patokan ini, tyernyata tidak semua peraturan hukum itu mengandung norma hukum di dalamnya. Beberapa peraturan yang demikian itu adalah ${ }^{51}$ :

1) Peraturan - peraturan yang termasuk ke dalam hukum acara

2) Peraturan - peraturan yang berisi rumusan - rumusan pengertian yang dipakai dalam suatu kitab hukum

3) Peraturan - peraturan yang memperluas, membatasi, atau mengubah isi dari peraturan lain

4) Peraturan - peraturan yang hanya menunjuk kepada peraturan lain

Pada prosesnya, Kelsen juga mengungkapkan sebuah teori jenjang (stufentheorie). Dalam teori itu Kelsen mengemukakan adanya dua sistem norma, yaitu sistem norma statis (nomostatics) dan sistem norma dinamik (nomodynamics). Norma statis adalah sistem yang melihat pada isi suatu norma, dimana suatu norma umum dapat ditarik menjadi norma khusus, atau norma khusus itu dapat ditarik dari suatu norma yang umum. Sistem norma yang

\footnotetext{
${ }^{51}$ Satjipto Rahardjo, Ilmu Hukum, PT.Citra Citra Aditya Bakti,Bandung,2012,h.33
} 
dinamik adalah suatu sistem norma yang melihat pada berlakunya suatu norma dari cara pembentukannya dan penghapusannya. Menurut Kelsen, norma itu berjenjang-jenjang dan berlapis-lapis dalam susunan yang hierarkis, dimana norma yang lebih tinggi berlaku, bersumber, dan berdasar pada norma yang lebih tinggi lagi, demikian seterusnya pada akhirnya „regressus' ini berhenti pada norma yang paling tinggi yang disebut norma dasar (grundnorm) yang tidak dapat lagi ditelusuri siapa pembentuknya atau dari mana asalnya. Norma dasar atau biasa yang disebut grundnorm, basicnorm, atau fundamentalnorm ini merupakan norma yang tertinggi yang berlakunya tidak berdasar dan tidak bersumber pada norma yang lebih tinggi lagi, tetapi berlaku secara presupposed, yaitu lebih dahulu ditetapkan oleh masyarakat ${ }^{52}$ Salah seorang tokoh yang mengembangkan teori tersebut adalah murid Hans Kelsen, yaitu Hans Nawiasky. Teori Nawiaky disebut dengan theorie von stufenufbau der rechtsordnung. Susunan norma menurut teori tersebut adalah ${ }^{53}$ :

1) Norma fundamental negara (Staatsfundamentalnorm);

2) Aturan dasar negara (staatsgrundgesetz);

3) Undang-undang formal (formell gesetz); dan

4) Peraturan pelaksanaan dan peraturan otonom (verordnung enautonome satzung).

Tata susunan norma hukum di negara Republik Indonesia merupakan juga norma hukum yang berjenjang-jenjang dan berlapis-lapis seperti dalam teori Hans Kelsen dan Hans Nawiasky, dan secara berurutan tata susunan norma

\footnotetext{
${ }^{52}$ Jimly Asshiddiqie "Teori Hans Kelsen tentang Hukum" Sekretariat Jenderal \& Kepaniteraan Mahkamah Konstitusi, Jakarta, 2006, hlm. 169-170

${ }^{53}$ A .Hamid Attamimi, Peranan Keputusan Presiden Republik Indonesia dalam Penyelenggaraan Pemerintahan Negara; Suatu Studi Analisis Mengenai Keputusan Presiden yang Berfungsi Pengaturan dalam Kurun Waktu Pelita I - Pelita IV, Disertasi, Ilmu Hukum Pasca Sarjana Universitas Indonesia, Jakarta, 1990,h.287
} 
hukum tersebut terdiri atas : Pokok-pokok pikiran dalam Pembentukan UndangUndang Dasar 1945 yaitu Pancasila, yang merupakan juga Norma Fundamental Negara (Staatsfundamentalnorm), kemudian Aturan-aturan Dasar/Pokok Negara (Staatsgrundgesetz) yang terdiri dari Batang tubuh Undang-Undang 1945, Ketetapan Majelis Permusyawaratan Rakyat, serta Konvensi Ketatanegaraan yang merupakan hukum dasar tak tertulis yang berlaku di Indonesia, kemudian Undang-Undang (Formell Gesetz), dan peraturan-peraturan lainnya seperti Peraturan Pemerintah, Keputusan Presiden, dan peraturanperaturan pelaksanaan lain di bawahnya (Verordnung danAutonome Satzung).

Untuk mengetahui kedudukan dari masing - masing aturan dalam sitem peraturan perundang - undangan indonesia, sebagaimana yang diatur dalam pasal 7 ayat (1) Undang - undang Nomor 12 Tahun 2011. Dalam pasal 7 ayat (1) UU No.12 Tahun 2011 menetapkan jenis dan hierarki perundang - undangan Republik Indonesia sebagai berikut :

1) Undang - Undang Dasar Negara Republik Indonesia Tahun 1945;

2) Ketetapan Majelis Permusyawaratan Rakyat;

3) Undang - Undang/ Peraturan Pemerintah Pengganti Undang- Undang;

4) Peraturan Pemerintah;

5) Peraturan Presiden;

6) Peraturan Daerah Provinsi; dan

7) Peraturan Daerah Kabupaten/ Kota

Selanjutnya dalam pasal 8 menyebutkan peraturan perundang - undangan selain yang disebutkan dalam pasal 7 ayat (1), yang mencakup peraturan yang ditetapkan oleh Majelis Permusyawaratan Rakyat, Dewan Perwakilan Rakyat, Dewan Perwakilan Daerah, Mahkamah Agung, Mahkamah Konstitusi, Badan Pemeriksa Keuangan, Komisi Yudisial, Bank Indonesia, Menteri, Badan, Lembaga atau Komisi yang setingkat yang dibentuk dengan undang - undang atau pemerintah atas perintah undang - undang, Dewan Perwakilan Rakyat Daerah 
Provinsi, Gubernur, Dewan Perwakilan Rakyat Daerah Kabupaten atau Kota, Bupati atau Walikota, Kepala Desa atau yang setingkat.

Berkaitan dengan kedudukan, tidak ada ketentuan yang secara tegas menetapkan dimana kedudukan peraturan - peraturan yang disebutkan dalam pasal 8 ayat (1) itu dalam hierarki peraturan perundang - undangan. Olehnya itu perlu kiranya dilakukan penafsiran, selanjutnya menurut Peter Mahmud Marzuki menyatakan perlunya melihat konsiderans "mengingat" karena dalam konsiderans itulah diacu peraturan perundang -undangan yang memerintahkan ${ }^{54}$. Adapun peraturan perundang - undangan yang diacu oleh PERMARI No.2 Tahun 2012 adalah sebagai berikut :

a. pasal 24 Undang - undang Dasar Tahun 1945, sebagaimana telah diubah dan ditambah, dengan perubahan keempat tahun 2002;

b. Undang - undang No.1 tahun 1946 Tentang hukum Pidana;

c. Peraturan Pemerintah Pengganti Undang - undang No.16 Tahun 1960 tentang Beberapa Perubahan Dalam Kitab Undang - undang Hukum Pidana sebagaimana telah ditetapkan dengan undang - undang melalui Undang undang No.1 Tahun 1961;

d. Peraturan Pemerintah Pengganti Undang - undang No.18 Tahun 1960 Tentang Perubahan Jumlah Denda dalam Kitab Undang - Undang Hukum Pidana dan Ketentuan - ketentuan Pidana Lainnya Yang Dikeluarkan sebelum 17 Agustus 1945 sebagaimana telah ditetapkan menjadi undang undang dengan Undang - undang No.1 tahun 1961;

e. Undang - undang No.18 Tahun 1985 sebagaimana telah diubah dengan Undang - undang No.5 Tahun 2004 tentang perubahan atas Undang undang No.18 Tahun 1985 Tentang Mahkamah Agung dan terakhir dengan Undang - undang No.3 Tahun 2009 Tentang Perubahan Kedua atas Undang - undang No.18 Tahun 1985 Tentang Mahkamah Agung;

f. Undang - undang No.8 Tahun 1981 Tentang Hukum Acara Pidana.

\footnotetext{
${ }^{54}$ Peter Mahmud Marzuki, Penelitian Hukum, Kencana,Jakarta, 2010, h.141 ( selanjutnya disingkat menjadi Peter II )
} 
Berdasarkan uraian diatas dapat diketahui bahwa peraturan yang memerintahkan atau yang menjadi acuan dibentuknya PERMARI N0.2 Tahun 2012 adalah undang -undang dasar tahun 1945, undang - undang , dan PERPU , maka dapat ditemukan kedudukan PERMARI No.2 tahun 2012 dalam hierarki perundang - undangan adalah berada dibawah Undang - undang atau setara dengan Peraturan Pemerintah. Artinya penerapan PERMA No.2 Tahun 2012 tersebut bertentangan dengan KUHP atau terjadi konflik aturan hukum.

Terhadap konflik aturan yang terjadi, maka pertama - tama kita harus mencari jawabannya di dalam undang - undang. Namun di dalam Undang Undang Nomor 12 Tahun 2011 Tentang Pembentukan Peraturan Perundang Undangan ( Lembaran Negara Republik Indonesia Tahun 2011 Nomor 82, Tambahan Lembaran Negara Republik Indonesia Nomor 5233, selanjutnya disingkat menjadi UU No.12 tahun 2011 ) tidak menemukan ketentuan yang mengatur apabila terjadi konflik aturan, menurut Yohanes Sogar Simamora, prinsip - prinsip hukum itu diperlukan sebagai dasar pembentukan aturan hukum dan sekaligus sebagai dasar dalam memecahkan persoalan hukum yang timbul manakala aturan hukum yang tersedia tidak memadai55. Asas - asas hukum yang digunakan dalam upaya menyelesaikan masalah hukum mengenai konflik aturan hukum, biasa dikenal dengan asas preferensi, yang terdiri dari asas lex superior derogat legi inferiori, lex specialis derogate legi generalis, dan lex posteriori derogate legi priori.

Salah satu alasan pembentukan PERMA No.2 Tahun 2012 adalah untuk menyesuaikan hukum dengan kondisi sosial masyarakat dan tidak bermaksud untuk merubah KUHP, sebagaimana yang termaktub dalam konsideran menimbang huruf ( e ) PERMA No.2 Tahun 2012 yang berbunyi " bahwa Peraturan Mahkamah Agung ini sama sekali tidak bermaksud mengubah KUHP,

\footnotetext{
${ }^{55}$ Yohanes Sogar Simamora, Prinsip Hukum Kontrak Dalam Pengadaan Barang Dan Jasa Oleh Pemerintah, Disertasi, Program Pasca Sarjana Universitas Airlangga,Surabaya,2005,h.22
} 
Mahkamah Agung hanya melakukan penyesuaian nilai uang yang sudah sangat tidak dengan kondisi sekarang ini. Hal ini dimaksudkan memudahkan penegak hukum khususnya hakim, untuk memberikan keadilan terhadap perkara yang diadilinya.", namun disisi lain, yang juga menjadi alasan dibentuknya PERMA No.2 Tahun 2012 adalah untuk merubah ketentuan beberapa pasal di dalam KUHP berkaitan dengan nilai barang dan jumlah denda, yakni ketentuan yang berbunyi " dua ratus lima puluh rupiah " dalam pasal 364,373,379,384,407 dan pasal 482 KUHP dibaca menjadi " dua juta lima ratus ribu rupiah. Dan jumlah denda dala KUHP kecuali pasal 303 ayat (1 dan 2 ), bis 303 ayat (1 dan 2 ) dilipatgandakan menjadi seribu kali. KUHP dalam hierarki perundang undangan yang berlaku di Indonesia merupakan Undang - undang, maka perubahannya harus dengan undang - undang juga. Sementara PERMA No.2 Tahun 2012 dalam hierarki perundang - undangan adalah dibawah undang undang. Dalam hal ini terdapat dua aturan hukum yang secara hierarki berbeda mengatur tentang batasan tindak pidana ringan, yang artinya telah terjadi konflik aturan. Dalam hal terjadi konflik aturan maka akan timbul persoalan kepastian hukum. Ketika konflik terjadi pada aturan yang secara hierarki berbeda maka kepastian hukum dapat dijamin dengan menerapkan asas lex superiori derogate legi inferiori yaitu aturan yang lebih tinggi mengesampingkan aturan yang lebih rendah. Dalam hal ini KUHP mengesampingkan PERMA No.2 Tahun 2012. Walaupun alasan diadakannya PERMA No.2 Tahun 2012 adalah agar tindak pidana ringan dapat ditangani secara proposional sehingga dapat memenuhi rasa keadilan, namun apabila peraturan tersebut bertentangan dengan peraturan yang lebih tinggi, maka peraturan tersebut batal demi hukum.

Apabila terjadi konflik aturan menimbulkan tidak-pastian hukum, untuk menjaga kepastian hukum, maka salah satu aturan harus dibatalkan. menurut Philipus M.Hadjon ${ }^{56}$, pembatalan tersebut ada dua macam, yakni pembatalan abstrak formal dan pembatalan praktikal. Pembatalan abstrak formal adalah

\footnotetext{
${ }^{56}$ Philpus M.Hadjon \& Tatiek Sri Djatmiati, Op.Cit, h.32
} 
pembatalan yang dilaksanakan oleh suatu lembaga khusus. Dalam hal ini pembatalan peraturan perundang - undangan yang kedudukannya dibawah undang - undang dilaksanakan oleh Mahkamah Agung. Selanjutnya pembatalan praktikal adalah suatu tindakan tidak menerapkan peraturan tersebut di dalam kasus konkrit.

2. PERMA No.2 Tahun 2012 ditinjau dari kekuatan mengikat dan kekuatan berlakunya peraturan perundang - undangan.

Ketentuan pasal 87 Undang - undang Nomor 12 Tahun 2011 tentang Pembentukan Peraturan Perundang - Undangan, yang berbunyi “ peraturan perundang - undangan mulai berlaku dan mempunyai kekuatan mengikat pada tanggal diundangkan, kecuali ditentukan lain dalam peraturan perundang undangan yang bersangkutan.". hal ini mensyaratkan bahwa semua bentuk peraturan perundang - undangan harus diundangkan agar dapat diberlakukan dan memilki kekuatan mengikat, adapun maksud dari frasa “ ditentukan lain " dalam peraturan perundang - undangan yang bersangkutan adalah bahwa berlakunya peraturan perundang - undangan yang tidak sama dengan dengan tanggal pengundangan dimungkinkan untuk persiapan sarana dan prasarana serta kesiapan aparatur pelaksana peraturan perundang undangan tersebut.

2.1. PERMA No.2 Tahun 2012 ditinjau dari kekuatan mengikatnya peraturan perundang - undangan.

Kekuatan berlakunya suatu peraturan perundang-undangan ini tidak sama dengan kekuatan mengikatnya. peraturan perundang - undangan mempunyai kekuatan mengikat sejak diundangkannya di dalam lembaran Negara atau di dalam Berita Negara. Ini berarti sejak dimuatnya dalam Lembaran Negara atau Berita Negara maka setiap orang terikat untuk mengakui eksistensinya. Dalam hal ini PERMA No.2 Tahun 2012 tidak ada dalam Berita Negara dengan kata lain 
tidak diundangkan ${ }^{57}$, yang mana berakibat PERMA tersebut tidak memilki kekuatan mengikat. Olehnya itu dapat dimengerti alasan dari dibuatnya Nota Kesepakatan Bersama ( Ketua Muda Pidana Khusus Mahkamah Agung RI, Direktur Jenderal Pemasyarakatan Kementrian Hukum dan Ham RI, Plt. Jaksa Agung Muda Tindak Pidana Umum Kejaksaan Agung RI, dan Kepala Badan Reserse Kriminal Kepolisian Negara RI ).

2.2. PERMA No.2 Tahun 2012 ditinjau dari kekuatan berlakunya peraturan perundang - undangan.

Sedangkan kekuatan berlakunya undang-undang menyangkut berlakunya undang-undang secara operasional. Peraturan perundang -undangan mempunyai persyaratan untuk dapat berlaku atau mempunyai kekuatan berlaku. Menurut Sudikno Mertokusumo, ada tiga macam kekuatan berlaku, yaitu kekuatan berlaku yuridis, sosiologis dan filosofis ${ }^{58}$.

\subsubsection{Kekuatan berlaku yuridis (Juristische Geltung)}

Undang-undang mempunyai kekuatan berlaku yuridis jika persyaratan formal terbentuknya undang-undang terpenuhi. Menurut Hans Kelsen yang dikutip oleh Sudikno Mertokusumo, kaedah hokum mempunyai kekuatan berlaku apabila penetapannya didasarkan atas kaedah yang lebih tinggi tingkatannya ${ }^{59}$. ini juga memilki arti bahwa peraturan perundang - undangan tersebut tidak boleh bertentangan dengan peraturan perundang - undangan yang lebih tinggi. Dalam hal ini PERMA No.2 Tahun 2012 yang kedudukannya dibawah undang - undang bertentangan dengan ketentuan pasal 364,373,379,384,407, dan pasal 482 KUHP, yang mana KUHP merupakan undang - undang. Maka dalam hal ni PERMA No.2 Tahun 2012 tidak memiliki kekuatan berlaku yuridis.

\footnotetext{
${ }^{57}$ ditjenpp.kemenkumham.go.id/database-peraturan

${ }^{58}$ Sudikno Mertokusumo III,Loc.Cit ,h.94

59ibid.h.95
} 


\subsubsection{Kekuatan Berlakunya Sosiologis (Soziologische Geltung)}

Berlaku atau diterimanya hukum di dalam masyarakat didasarkan pada kenyataan dalam masyarakat. Kekuatan berlakunya hukum di dalam masyarakat ini ada dua macam, yaitu:

1) menurut teori kekuatan (Machtstheorie) hukum mempunyai kekuatan berlaku sosiologis apabila keberlakuannya dipaksa oleh penguasa, terlepas dari diterima ataupun tidak oleh warga masyarakat,

2) menurut teori pengakuan (Anerkennungstheorie) hukum mempunyai kekuatan berlaku sosiologis apabila diterima dan diakui oleh warga masyarakat.

Bahwa dengan dibuatnya Nota Kesepakatan Bersama tanggal tujuh belas bulan oktober tahun dua ribu dua belas, terkesan memaksakan diberlakukannya PERMA No.2 Tahun 2012 oleh para penegak hukum. selanjutnya oleh terdakwa penerapan PERMA tersebut dirasakan proporsional jika dibandingkan dengan ketentuan KUHP yang mengatur tentang tindak pidana ringan. Maka tidak heran jika sebagian besar terdakwa atau penasehat hukum menggunakan PERMA No.2 Tahun 2012 sebagai dasar eksepsi terhadap tindak pidana yang menimbulkan kerugian harta benda yang harganya tidak melebihi dua juta lima ratus rupiah . dalam hal ini PERMA No.2 Tahun 2012 memiliki kekuatan berlaku sosiologis.

\subsubsection{Kekuatan Berlaku Filosofis (Filosofische Geltung)}

Hukum mempunyai kekuatan berlaku filosofis jika kaedah hukum tersebut sesuai dengan cita-cita hukum (Rechtsidee) sebagai nilai positif yang tertinggi (dalam hal ini harus sesuai dengan tujuan dari Pancasila yaitu untuk mencapai masyarakat yang adil dan makmur). Bahwa yang menjadi landasan filosofi dibentuknya PERMA No.2 Tahun 2012 adalah untuk memberikan keadilan kepada masyarakat melalui penanganan tindak pidana ringan secara proporsional dengan menyesuaikan nilai rupiah dalam KUHP dengan situasi dan 
kondisi sosial masyarakat saat ini. Dalam hal ini PERMA No.2 Tahun 2012 memiliki kekuatan berlaku filosofis.

Perubahan pada pasal - pasal di dalam KUHP merupakan materi perubahan undang - undang, sedangkan dibentuknya PERMA No.2 Tahun 2012 bertujuan untuk mengadakan penyesuaian terhadap batasan tindak pidana ringan dan jumlah denda dalam KUHP yang juga berarti menyimpangi terhadap ketentuan pasal - pasal yang disesuaikan tersebut, maka berdasarkan kedudukan/ hierarki dan kekuatan berlaku serta kekuatan mengikat suatu peraturan perundang - undangan, maka PERMA No.2 Tahun 2012 tidak mempuyai kekuatan berlaku dan kekuatan mengikat.Berdasarkan uraian diatas maka PERMA No.2 Tahun 2012 memenuhi unsur kekuatan berlaku sosiologis dan filosofis, sementara kekuatan berlaku yuridis tidak terpenuhi, artinya ada satu unsur tidak terpenuhi . Menurut Sudikno Mertokusumo, Agar berfungsi, maka kaedah hukum harus memenuhi ketiga unsure tersebut: harus mempunyai kekuatan berlaku yuridis, sosiologis dan filosofis sekaligus ${ }^{60}$.

3. Alasan Hakim Menerapkan PERMA No.2 Tahun 2012

Beranjak dari pertimbangan atau alasan yang digunakan majelis hakim menerapkan PERMA No.2 Tahun 2012 yang terdapat dari kedua putusan tersebut diatas, bahwa tidak dibatalkannya PERMA No.2 Tahun 2012 melalui uji materi di Mahkamah Agung dan adanya Nota Kesepakatan Bersama. Bahwa berdasarkan pasal 87 Undang - undang No.12 Tahun 2011 peraturan perundang - undangan mulai berlaku dan mempunyai kekuatan hukum mengikat sejak tanggal diundangkan. Bahwa sebagai salah satu peraturan perundang undangan PERMA No.2 Tahun 2012 belum diundangkan, olehnya itu PERMA No.2 Tahun 2012 tidak berlaku dan tidak mempunyai kekuatan mengikat. selain dari pada itu PERMA No.2 Tahun 2012 juga bertentangan dengan asas hierarki karena bertentangan dengan aturan yang lebih tinggi yakni KUHP. Serta materi

\footnotetext{
60ibid.h.96
} 
muatan PERMA No.2 Tahun 2012 bertentangan dengan ketentuan pasal 15 ayat (1) UU No.12 Tahun 2011 yang berbunyi " materi muatan mengenai ketentuan pidana hanya dapat dimuat dalam : a.Undang - undang, b.Peraturan Daerah Provinsi, c.Peraturan Daerah Kabupaten/Kota". Selanjutnya mengenai Nota Kesepakatan bersama, berdasarkan pasal 7 ayat (1) undang - undang No.12 Tahun 2011 yang mengatur tentang jenis dan hierarki peraturan perundang undangan tidak ditemukan jenis peraturan berupa Nota Kesepakatan Bersama. Artinya Nota Kesepakatan Bersama tidak termasuk dari salah satu peraturan perundang - undangan yang berlaku di Indonesia sehingga tidak memilki kekuatan mengikat.

Apabila terjadi konflik aturan maka demi kepastian hukum salah satu aturan tersebut harus dibatalkan.menurut Philipus Hadjon dan Tatiek Sri Djatmiati61 ada dua macam pembatalan pertama abstrak formal melalui yudisial review di Mahkamah Agung. Dan pembatalan yang kedua praktikal yaitu pembatalan melalui putusan hakim yang tidak menerapkan aturan tersebut dalam kasus konkrit. hakim harus dapat memberikan kepastian hukum dalam putusan yang dibuatnya, olehnya itu hakim harus membatalkan salah satu aturan dengan berdasarkan asas preferensi. Menurut Peter Mahmud Marzuki, dalam menjaga kepastian hukum, peran pemerintah dan pengadilan sangat penting. Pemerintah tidak boleh menerbitkan aturan pelaksanaan yang tidak diatur oleh undang undang atau bertentangan dengan undang - undang. Apabila hal itu terjadi, pengadilan harus menyatakan bahwa peraturan demikian batal demi hukum, artinya dianggap tidak pernah ada sehingga akibat yang terjadi karena adanya peraturan itu harus dipulihkan seperti sediakala ${ }^{62}$.

Menurut Notohamidjojo yang dikutip oleh Suparto, hakim seharusnya dan sepatutnya bekerja dengan asas-asas hukum apabila ia harus melakukan penafsiran pada artikel-artikel yang kurang jelas, dan dengan menggunakan asas

\footnotetext{
${ }^{61}$ Philipus M Hadjon dan Tatiek Sri Djatmiati,Loc.Cit,h.32

${ }^{62}$ Peter Mahmud II, Op.Cit.h.138
} 
hukum hakim dapat mengadakan penetapan (precisering) dari pada keputusankeputusannya ${ }^{63}$.

Secara teori apabila sebuah aturan hukum bertentangan dengan aturan hukum yang lebih tinggi maka aturan hukum yang lebih rendah tersebut batal demi hukum yang artinya dianggap sejak semula aturan hukum tersebut tidak ada, yang tidak perlu diadakan upaya untuk membatalkan aturan tersebut, namun pada kenyataan tetap harus ada upaya pembatalan yudisial review di Mahkamah Agung, hal ini terbukti dengan adanya alasan hakim yang tertuang dalam Putusan Nomor : 553/Pid.B/2012/PN.Stb. yang berpendapat bahwa PERMA No.2 Tahun 2012 sebagai salah satu bentuk peraturan perundang undangan yang ada dalam sistem hukum di Indonesia, berlaku dan memiliki kekuatan mengikat selama tidak dibatalkan melalui uji materil ke Mahkamah Agung.

Pembatalan selanjutnya dapat melalui putusan hakim di pengadilan. Dengan berdasarkan asas hierarki perundang - undangan dan syarat berlakunya suatu peraturan perundang - undangan ( pasal 87 UU No.12 Tahun 2011 ) hakim dapat mengesampingkan PERMA No.2 Tahun 2012. Namun kenyataan yang terjadi hakim lebih tunduk kepada kesepakatan bersama dari pada undang - undang dan asas hukum sebagaimana yang tertuang dalam Putusan Sela Nomor : 327/Pid.B/2012/PN.SKG. dalam hal ini penemuan hukum yang dilakukan oleh hakim dalam putusan ini tidak menggunakan sumber - sumber hukum pidana dan asas -asas hukum yang diakui. Penerapan PERMA No.2 Tahun 2012 dengan berdasarkan Nota Kesepakatan Bersama merupakan pelecehan terhadap kebebasan hakim karena hakim sepatutnya hanya tunduk pada hukum yang berlaku. Undang - undang telah memberikan kebebasan kepada hakim untuk melakukan penemuan hukum agar putusan yang dibuat dapat tidak bertentangan dengan rasa keadilan. Artinya dengan tunduk kepada

\footnotetext{
63 Suparto, Demi Keadilan dan Kemanusiaan, Beberapa Cabang Filsafat Hukum, Gunung Mulia,Jakarta, 1975, h. 49-50.
} 
hukum yang berlaku hakim dapat membuat putusan yang adil. Apabila aturannya tidak jelas atau aturannya sudah tidak sesuai dengan situasi dan kondisi masyarakat hakim dapat menggunakan metode penafsiran.

\section{PENUTUP}

\section{KESIMPULAN}

Kedudukan PERMA No.2 Tahun 2012 dalam hierarki perundang - undangan adalah dibawah Undang - undang dan Ketentuan PERMA No.2 Tahun 2012 yang bermaksud merubah ketentuan dalam pasal 364,373,379,384,407, 482, semua ketentuan yang mengatur tentang denda, kecuali pasal 303 ayat (1 dan 2 ) bis 303 ayat (1 dan 2 ) KUHP adalah bertentangan dengan asas kesesuaian jenis, hierarki, dan muatan peraturan perundang - undangan yang berakibat batal demi hukum berdasarkan asas preferensi.

\section{DAFTAR PUSTAKA}

Ali, Ahmad, Menguak Tabir Hukum, Suatu Kajian Filosofis dan Sosiologis, Candra Pratama, Jakarta,1996.

Arbijoto,Kebebasan Hakim,Diadit Media,Jakarta,2010.

Asikin ,Zainal, Pengantar Ilmu Hukum, PT. Rajagrafindo Persada, Jakarta,2012.

A.Soetomo,Pedoman Dasar Pembuatan Surat Dakwaan dan Suplemen ,Pradnya Paramita,Jakarta,1999.

Attamimi,A .Hamid, Peranan Keputusan Presiden Republik Indonesia dalam Penyelenggaraan Pemerintahan Negara ; Suatu Studi Analisis Mengenai Keputusan Presiden yang Berfungsi Pengaturan dalam Kurun Waktu Pelita I - Pelita IV, Disertasi, Ilmu Hukum Pasca Sarjana Universitas Indonesia, Jakarta, 1990.

Bahiej,Ahmad, Sejarah dan Problematika Hukum Pidana Materiel di Indonesia, Sosio Religia,Vol.4 No.4 Agustus 2005. 
Effendy ,Marwan, Diskresi,Penemuan Hukum, Korporasi \& Tax Amnesty Dalam Penegakan Hukum,Referensi,Jakarta,2012.

Hadjon ,Philpus M. \& Tatiek Sri Djatmiati, Argumentasi Hukum , Gadjah Mada University Press,Yogyakarta, 2011.

Hamzah, Andi, Asas-Asas Hukum Pidana , Rineka Cipta,Jakarta,2010.

Harahap M.Yahya, Kedudukan kewenangan dan acara peradilan agama, Sinar Grafika, Jakarta,2005.

Hiariej,Eddy O.S, Asas Legalitas dan Penemuan Hukum dalam Hukum Pidana,Erlangga, Jakarta,2009.

Loudoe,Jhon Z, Menemukan Hukum Melalui Tafsir Dan Fakta, Bina Aksara,Jakarta,1985.

Marzuki ,Peter Mahmud, Penelitian Hukum,Kencana,Jakarta,2000.

Marzuki Peter Mahmud, Pengantar Ilmu Hukum, Kencana, Jakarta, 2013.

Mertokusumo, Sudikno \& A.Pitlo, Bab - Bab Tentang Penemuan Hukum, PT.Citra Aditya Bakti,Bandung,1993.

Mertokusumo ,Sudikno, Penemuan Hukum, Liberty, Yogyakarta, 2004.

Mertokusumo ,Sudikno,Mengenal Hukum, Liberty , Yogyakarta,2008.

Moeljatno, Asas - Asas Hukum Pidana, Rineka Cipta,Jakarta,2000.

Prodjodikoro,Wirjono, Asas - Asas Hukum Pidana di Indonesia, Refika Aditama,Bandung,2009.

Purwoleksono, Didik Endro ,Hukum Pidana,Airlangga University Press,Surabaya,2014.

Rahardjo,Satjipto, Ilmu Hukum, PT.Citra Citra Aditya Bakti,Bandung,2012.

Simamora, Yohanes Sogar, Prinsip Hukum Kontrak Dalam Pengadaan Barang Dan Jasa Oleh Pemerintah, Disertasi, Program Pasca Sarjana Universitas Airlangga,Surabaya,2005. 